\title{
DIGITAL MARKETING FOR SMES OPERATED BY HOUSEWIVES OF MALAKA SARI IN PANDEMIC SITUATION
}

\author{
Leo Andri Yulius CAESAR ${ }^{1 *}$, Anisa LARASATI ${ }^{2}$, Nuril Kusumawardani Soeprapto PUTRI ${ }^{3}$, Sulistyo \\ HERIPRACOYO ${ }^{4}$, Sevenpri CANDRA ${ }^{5}$ \\ ${ }^{1,2,5}$ Management Department, BINUS Business School Undergraduate Program, Bina Nusantara University, \\ Jakarta 11480, Indonesia \\ ${ }^{3,4}$ Information Systems Department, School of Information Systems, Bina Nusantara University, Jakarta 11480, Indonesia \\ *seven@binus.ac.id
}

\begin{abstract}
Covid-19 pandemic affected people's lives and economic situation. In Malaka Sari, East Jakarta, Housewives were adapting to the situation by establishing home industry SMEs that produced several products, including products from used cooking oil as material. Due to pandemics, physical marketing was restricted, and these housewives could not promote their product physically and only has customers from the vicinity. Binus assisted by providing training to these housewives in Digital Marketing to increase their exposure and strategies. Four training sessions were held with topics in Digital Marketing, Consumer Behavior, Customer Engagement, and Social Media Marketing. This training was held successfully with positive feedback from participants.
\end{abstract}

Keywords: Digital Marketing, SME, Social Media, Pandemic

\section{BACKGROUND}

During pandemic situations, several sectors are heavily impacted, including small and medium enterprises. Many SMEs experience a drop in sales or difficulties in developing or marketing their products. Some productionbased SMEs are home industries producing consumer products from readily available materials such as used cooking oil. With the Covid-19 situation causing uncertainty in people's daily lives, many families can feel the economic impact. Located in East Jakarta, families in Malaka Sari also felt the impact, and the housewives decided to come up with a solution. In order to help their families' economic situation, these housewives are members of PKK. Malaka Sari (Housewives community in Malaka Sari) used their creativity to use cooking oil to produce daily necessities such as soaps, candles, and detergents.

These products were marketed to communities or households near the vicinity. To help their families' economic situation, these products also serve another benefit. By utilizing used cooking oils, the housewives of Malaka Sari have unintentionally supported environmental sustainability. They are utilizing household waste to produce valuable products, reducing waste damage, and promoting recyclability. While the intention is excellent, several problems need solutions. Since the products are marketed locally, there is a limited number of customers. Another problem is that due to Covid-19, it is impossible to perform physical promotion freely. So, the housewives in Malaka Sari deal with the limited promotion and sales activities while facing the need to increase sales and reach more customers.

One of the solutions to this problem is digital marketing. With the availability of the internet, sales and promotion activities do not have to be performed physically. By utilizing digital marketing, potential customers can increase, and customer engagement can be performed without physical interaction. So, our solution as a team from Binus for this problem is to provide digital marketing training for our partner (housewives in Malaka Sari), including consumer behavior, customer engagement, and social media strategies.

\section{PARTNER'S ANALYSIS Products}

By utilizing cooking oils, housewives in Malaka Sari created daily necessities such as candles, soaps, and detergents. These products are safe for human usage and especially pleasant for the environment because they minimized household waste (used cooking oils). These products were produced in the small-scale home industry and packaged in simple packages. Promotion and marketing were performed through word of mouth and social media to customers who are households near the vicinity.

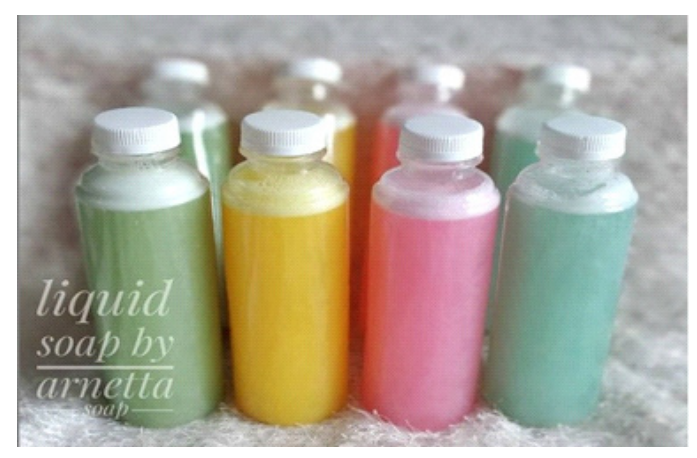

Picture 1. Liquid Soaps

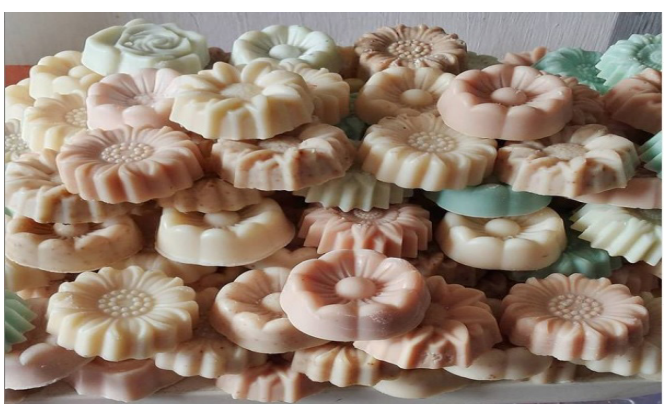

Picture 2. Detergent Soaps 


\section{Problems}

The partner faces several identified problems. These problems are:

1. Limited promotion and marketing activity due to Covid-19. There is no physical promotion and marketing activity that the partner can perform.

2. Limited customers. Due to limited promotion and marketing activity, these products can only reach a limited number of customers.

3. Social media utilization. While social media has been used for promotion and marketing activities, the utilization is not optimum yet.

4. Digital marketing strategies. Partners possess limited knowledge regarding digital marketing and strategies needed for their marketing and promotion activities.

In this digital era, promoting through the internet, digital technology, or digital marketing becomes necessary. The approach is, however, different from traditional marketing. Digital marketing encourages twoway communication instead of one-way (Järvinen et al., 2012), shifts power from marketers to customers (HennigThurau et al., 2010), focuses on accurate information about the brand instead of marketing messages (Christodoulides, 2009), and finally, focuses on managing customer relationship (Hennig-Thurau et al., 2010). This leads Binus to held training with Digital Marketing topic to increase the awareness to communicate two ways; Consumer Behavior topic to understand customers, who have the power in this digital era; Social Media Marketing topic to learn on giving objective information about the brand; and Customer Engagement topic to engage and manage the customer relationship.

Digital marketing is done through the use of social media tools, such as social networks (Facebook, Twitter, Instagram, YouTube, WhatsApp), blogs, microblogs, communities (Weinberg and Pehlivan, 2011; Järvinen et al., 2012; Marušić and Vranešević, 2021). Those that are not familiar with these tools could not reflect good results. Many SMEs still use social media as one-way broadcasting and have not used digital marketing tools' full potential (Taiminen and Karjaluoto, 2014).

In order to use social media effectively, understanding consumers and manage customer relationships is essential (Rowley, 2008; Hennig-Thurau et al., 2010). Some consumer behavior that needs to be considered is whether the given choice set might confuse them (Dhar, 1997) and which online reviews could help them choose (Liu et al., 2011). Finally, understanding customer values is needed to work towards the co-creation of customer experiences and manage the customer relationship (Rowley, 2008).

\section{RESULTS AND DISCUSSION}

The proposed solution to handle problems faced by the partner was to provide several training sessions through online meetings. These sessions included several topics that can be learned and utilized by the partner to handle their problems. Four sessions were held covering different topics regarding digital marketing and strategies to develop partner's products and marketing plans. Each session was facilitated by a Subject Matter Expert (S.M.E.) relevant to the field, providing theoretical insights and action suggestions that the partner can immediately perform. The four training sessions were:

1. Digital Marketing training session held on July 5th, 2021. Dr. Sulistyo Heripracoyo facilitated this session, SIP, MM, and Nuril Kusumawardhani Soeprapto Putri, ST, MKM. In this session, SMEs provided a general introduction to Digital Marketing concepts and practices while giving practical suggestions on utilizing blogs as a marketing tool. Participants were provided with tutorials and examples on creating efficient and effective blogs.

2. Consumer Behavior training session held on July 6th, 2021. This session was facilitated by Anisa Larasati, SE, MBA, Ph.D. In this session, SME provided insights into consumers' behavior, starting from problems that consumers face, problems of choices, and tactics to deal with consumers' problems. Participants were also actively engaged in discussions on how to understand their consumers through digital marketing media effectively.

3. Customer Engagement training session held on July 7th, 2021. This session was facilitated by Dr. Leo Andri Yulius Caesar, S.Kom, M.M. In this session, SME provided insight on using social media as engagement tools and providing message and storytelling tactics. Participants were actively engaged in discussions to review their current practices in utilizing social media as engagement tools.

4. Social Media Marketing training session held on July 8th, 2021. This session was facilitated by Dr. Ir. Sevenpri Candra, S.Kom, S.E, M.M., ASEAN Eng. In this session, SME provided strategies and tactics in performing marketing using social media. Participants were presented with comprehensive strategies to perform marketing and summarize activities from previous sessions.

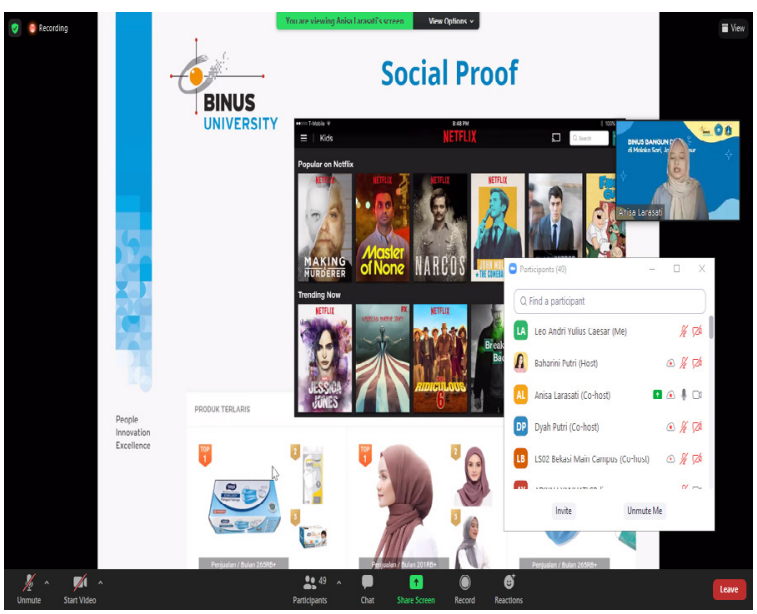

Picture 3. Training Session Picture 1 


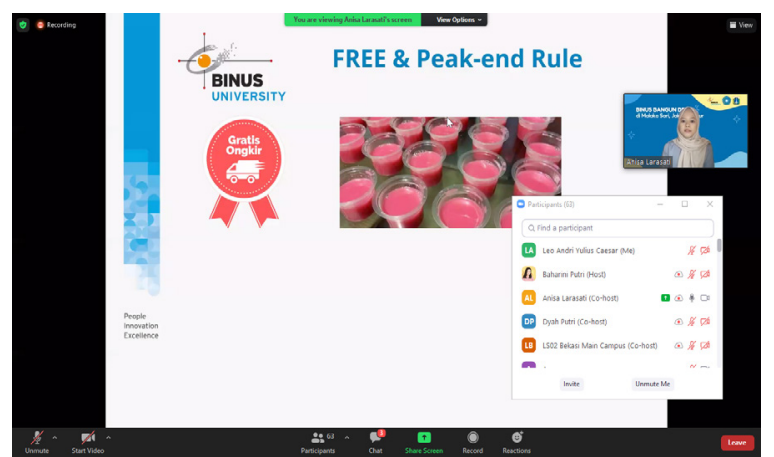

Picture 4. Training Session picture 2

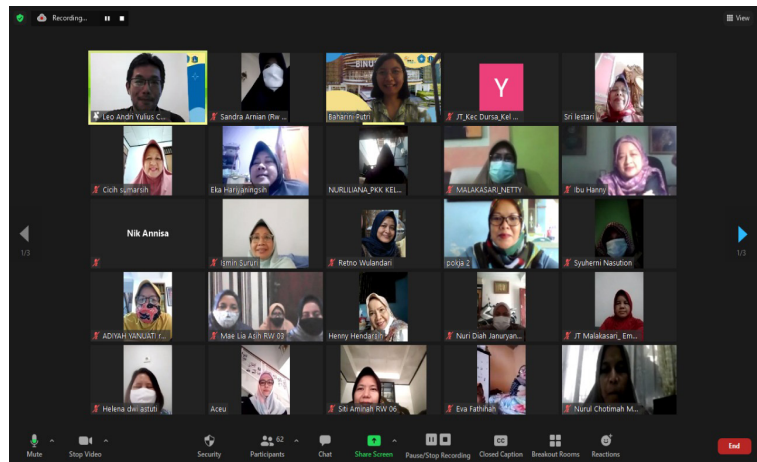

Picture 5. Some of the Training Participants

60 to 90 participants attended each session's training session, and the engagement level was good as participants actively asked questions and engaged in lively discussions. The partner's review of the training sessions was positive, and in the partner's perception, the training sessions provided their insights and practical strategies that partner's members can utilize.

\section{CONCLUSION}

Training sessions were held successfully and provided benefits for partner members. These training sessions provided solutions to handle problems faced by the partner.

1. Digital marketing is the solution for local physical marketing and promotion. With digital marketing, these activities can be performed through digital media without physical interaction and can reach more comprehensive potential customers.

2. With digital marketing, a partner is not restricted to potential customers near the vicinity. Digital marketing can reach more expansive areas through social media and engage more customers.

3. Partner's members were provided with training and strategies to utilize social media to understand their consumer's behavior, engage their customers, and utilize their social media as tools for digital marketing.
4. Through the training sessions, partner members were equipped with strategies and action plans in digital marketing that increase their digital presence and exposure.

\section{REFERENCES}

Bradburn, N., Sundman, S., \& Wansink, B. (2004). Asking questions: The definitive guide to questionnaire design. San Fransisco: Jossey-Bass.

Christodoulides, G. (2009). "Branding in the Post-Internet Era”. Marketing Theory, 9(1), 141-144.

Dhar, R. (1997). "Consumer Preference for a No-Choice Option". Journal of Consumer Research, 24 (September), 215-231.

Hennig-Thurau, T., Malthouse, E. C., Friege, C., Gensler, S., Lobschat, L., Rangaswamy, A., \& Skiera, B. (2010). "The Impact of New Media on Customer Relationships". Journal of Service Research, 13(3), 311-330.

Järvinen, J., Tollinen, A., Karjaluoto H., \& Jayawardhena C. (2012). "Digital and Social Media Marketing in B2B Industrial Section". The Marketing Management Journal, 22(2), 102-117.

Kumaidi. (2004). Pengukuran Bekal Awal Belajar dan Pengembangan Tesnya. Jurnal Ilmu Pendidikan, 5(4).

Liu, Q. Karahanna, E., and Watson, R. T. (2011). "Unveiling User-Generated Content: Designing Websites to Best Present Customer Reviews". Business Horizons, 54, 231-240.

Marušić, T. \& Vranešević, T. (2021). "Challenges of Navigating Brands Through Social Media Marketing Managers Point of View". In press. https://doi.org/10.32910/ep.72.3.4

Rowley, J. (2008). "Understanding Digital Content Marketing”. Journal of Marketing Management, 24(5-6), 517-540.

Simbolon, M. (2012). "Perilaku bullying pada mahasiswa berasrama”. Jurnal Psikologi, 39(2), 233-243.

Taiminen, H. M. \& Karjaluoto, H. (2014). The Usage of Digital Marketing Channels in SMEs. Journal of Small Business and Enterprise Development, 22(4), 633-651.

Weinberg, B. D. \& Pehlivan, E. (2011). "Social Spending: Managing the Social Media Mix". Business Horizons, 54, 275-282. 